\title{
DIE EERSTE VRYHEIDSOORLOG: ENKELE ASPEKTE MBT DIE BRITSE SIENING VAN DIE BOERE EN DIE VERSKILLE TUSSEN BOER EN BRIT
}

\author{
${ }^{*}$ Kapt G. E. Visser
}

\begin{abstract}
This article draws a comparison between the Boer and British Forces engaged in the war of 1880 - 1881 between the Zuid-Afrikaansche Republiek and England. It also depicts the gross underestimation of the Boer forces by the British during this war as main reason for the latter's defeat.
\end{abstract}

Met die anneksasie van die 'Zuid-Afrikaansche Republiek' op 12 April 1877, het Groot-Brittanje ingemeng met die bestaansreg van 'n Boerevolk van wie hy bitter min geweet of begryp het. Die verdraaide beeld wat hy van die Transvaal en sy mense gehad het, het die filantrope in Engeland en die Bevooroordeelde Britse amptenare in Suid-Afrika vir hom opgetower.

Die Britse amptenare in Suid-Afrika het feitlik sonder uitsondering die uitbreiding van die Britse Ryk as hul hoogste roeping beskou. Met die oog daarop, het hulle nie geskroom om leuens te gebruik om die kolonisasie-trae regering in Engeland te oorreed om die Transvaal te annekseer nie. Hulle het verklaar dat die Transvaalse burgers die mees agterlike Blanke gemeenskap in die wêreld was en dat anneksasie vir hulle 'n verlossing sou wees. Die uitbreiding van die Britse gesag oor die Transvaal is gevolglik as ' $n$ daad van menslikheid wat die armsalige Boere uit die kloue van hul eie armoede en onnoselheid sou red, voorgehou. Om hul saak te sterk, is die Britse Regering verseker dat die oorgrote meerderheid van die Transvaalse burgers in elk geval ten gunste van anneksasie was.

Die filantrope in Engeland het eweneens die anneksasie van die Transvaal bepleit, maar onder 'n ander voorwendsel. Volgens hulle het die Boere die swart volke in hul omgewing gruwelik onderdruk en mishandel en was swart slawerny aan die orde van die dag. Die Britse Blou Boeke het dan ook 'n indrukwekkende lys van beweerde gevalle van slawerny, mishandeling en ander wandade teenoor die Swartes ter regverdiging van die anneksasie aangehaal.

Die onwaarheid van die beskuldigings aangaande slawerny en die onderdrukking van die swart volke is deur die anneksasie self bewys. Die
Driemanskap het in dié verband in 'n proklamasie wat in Desember 1880 te Paardekraal uitgereik is, verklaar dat '. . . Hoewel van verschillende zijden dikwijls aan de Republiek verweten is geworden de slavernij te bevorderen, is de onwaarheid dier beschuldigingen schitterend aan het licht getreden, juist door de annexatie; de vertegenwoordigers van Hare Majesteit in ons land hebben geen gelegenheid gehad eenig onregt aan de kaffers, door de Boeren aangedaan, te herstellen, om de eenvoudige reden dat er geen één begaan was; in het gansche land is geen enkele slaaf vrij gemaakt, omdat er geen enkele was'. ${ }^{1}$

Die Britse Regering het nie die ware aard en karakter van die Boere-volk geken of die diepte van hul vryheidsliefde begryp nie. Dit is eers as 'n mens die boustene van die Boere-volk ontleed, dat jy besef hoe diep die vryheidsdrang in hul wese gewortel was. Paul Kruger het in die verband die vraag gestel 'Wie Zijn wij?' en daarop geantwoord 'Afstammelingen van de Hollandsche Kolonisten van de Kaap de Goede Hoop, en bestaande uit zuivere Hollandsche mannen en uit nakomelingen van die Rèfugées ... ${ }^{2}$ Hy gaan voort en sê dat uit die '. . . aangeboren geest van vrijheid en zelfbestuur ...' van die Hollanders, $\therefore$... wist uitstekend goed triomferen over de despotieke politiek der Oost-Indische Compagnie ...' en die 'vurig geloof en den geest van zelfopoffering (van de Franse Rèfugées), die hun eigen vaderland onder Lodewijk XIV had doen verlaten ... groeide één Volk op, één in geloof, één in rustigen eerbied voor de Wet, maar met een gevoel van vrijheid en onafhankelijkheid, even grootsch als de vlakten ruim waren en wijd .3

Vir ' $n$ volk met so 'n agtergrond sou berusting by die anneksasie die verloëning van hul vryheidsliefde beteken. En dit kon hulle nie. Hulle 
het die Britse bestuur in Transvaal as '... een spotvertegenwoordiging, enkel uit oogendienaars van de overweldigers samengesteld . . . ${ }^{4}$ beskou en onomwonde verklaar dat hulle eerder vir ewig as onbeskaafdes in die wildernis as onder die Britse vlag sou woon.

Die anneksasie het weinig belangstelling en feitlik geen simpatie vir die Boere in Brittanje gewek nie. Slegs 'n handjievol radikales, wat die Britse Ruk as 'half blunder and half crime' ${ }^{5}$ beskou het, het die vernietiging van die klein Boere-nasie se onafhanklikheid teengestaan. Die res het hulle weinig aan die gebeure in hierdie afgeleë uithoek van die wêreld gesteur.

Die gedrag van die Britse troepe na anneksasie het nie juis daartoe bygedra om die Boere se goedgesindheid te wen nie. 'n Senior Britse offisier, kolonel Bellairs, het in die verband gekla dat sy manskappe hulle gedra het asof hulle in vyandsland was. Hulle het mense aangerand, winkels geplunder, perde gesteel, beeste geskiet en oor die algemeen alle grense van ordelikheid oorskry. Sommige van die jong offisiere of van die wat pas in Suid-Afrika aangekom het, het ook 'n swak voorbeeld vir hul minderes gestel. Hulle het die Afrikaner bespot en met minagting behandel en hom dikwels die voorwerp van hul grappe gemaak om hul verveeldheid te verdryf. ${ }^{6}$

Die Engelse idee van dorpsontwikkeling het ook lynreg teen die beginsels van die konserwatiewe, godsdienstige Boere ingedruis. Die Boere het gekla dat oral waar die Engelse 'n dorp uitlê, hulle heel eerste ' $n$ hotel en 'n kantien bou. Daarna het hulle 'n tronk gebou om die dronkaards in toe te sluit. Die Boere daarteenoor, het by 'n stigting van 'n nuwe dorp altyd eers 'n kerk en 'n skool gebou, voordat hulle aan enigiets anders aandag gegee het.

$\mathrm{Na}$ 'n uitgerekte periode van passiewe verset en verskeie pogings deur Paul Kruger en ander volksleiers om die anneksasie opgehef te kry, is daar op 11 Desember 1880 op 'n volksvergadering te Paardekraal besluit om die Republiek in ere te herstel. Die landsbestuur is op 31 Desember 1880 aan die sogenaamde 'Driemanskap', naamlik Paul Kruger, Piet Joubert en M. W. Pretorius opgedra. Die Vierkleur is op 16 Desember 1880 op Heidelberg gehys en die Driemanskap het geëis dat sir Owen Lanyon, wat Shepstone as administrateur van Transvaal opgevolg het, die landsregering op vreedsame wyse aan hulle oordra.
Lanyon het geweier om die regering oor te dra, want hy het nie geglo dat die Boere werklik die Britte in 'n volskaalse oorlog sou aandurf nie. Hy het die Boere as 'n spul lafaards beskou wat wreed en meedoënloos teenoor hul swakkeres sou optree, maar wat nie die moed sou hê om teen die magtige Britse leër te veg nie. Verder het hy ook beweer dat die Boereleiers nooit daarin sou slaag om die Boerevolk tot ' $n$ verenigde front teen die Britte saam te snoer nie, aangesien daar nie werklik by hulle ' $n$ begeerte was om hulle teen die anneksasie te verset nie. Hy het voorts beweer dat gewetenlose opstokers soos Kruger en Joubert die Boere se liggelowigheid uitgebuit het om hulle in opstand te bring. In die proses sou hulle onder andere verkondig het dat die Britse Regering van plan was om hul kerk en taal in die ban te doen en dat hul seuns gedwing sou word om vir Brittanje in Indië te gaan veg.

Sir Garnet Wolseley, wat in September 1879 as Goewerneur van Transvaal en Hoë Kommissaris van Transvaal en Natal benoem is, is die taak opgedra om die ontevredenheid in die Transvaal te beredder. Hy het egter geen simpatie met die Boere gehad nie en het hulle, soos die meeste van sy kollegas, as die agterlikste Blanke gemeenskap in die wêreid beskou. Daarby het hy ook geglo dat hulle inherent 'n spul lafaards was wat oor al die sluheid en wreedheid van die swartman beskik het, maar nie sy moed en eerlikheid besit het nie. Hulle sou genadeloos teenoor 'n gevalle vyand optree, maar sou nie 'n uur teen die Britse leër staande kon bly nie. Die verskeie volksvergaderings wat die Boere gehou het, het by hom die indruk gewek dat hulle daarvan gehou het om bymekaar te kom en groot te praat, maar nie die moed gehad het om op te tree nie.

Alhoewel die meerderheid Britte die siening van manne soos Lanyon en Wolseley onderskryf het, was daar tog 'n handjievol wat besef het dat die Boere, of ten minste 'n gedeelte van hulle, nooit die Britse gesag sou aanvaar nie. Onder hierdie groepie het ook generaal-majoor sir George Pomeroy Colley, die Britse hoë Kommissaris vir Suidoos-Afrika en Goewerneur van Natal, getel. Hy het in 1879 na 'n ontmoeting met generaal Piet Joubert verklaar: ' . . There are a certain number of obstinate, almost fanatical, old Dutchmen, whom one cannot help rather admiring, and who will sacrifice everything and abandon their farms rather than to live under the British flag, or, indeed under any form of government but their own'.

Toe die eerste skote op 16 Desember 1880 by 


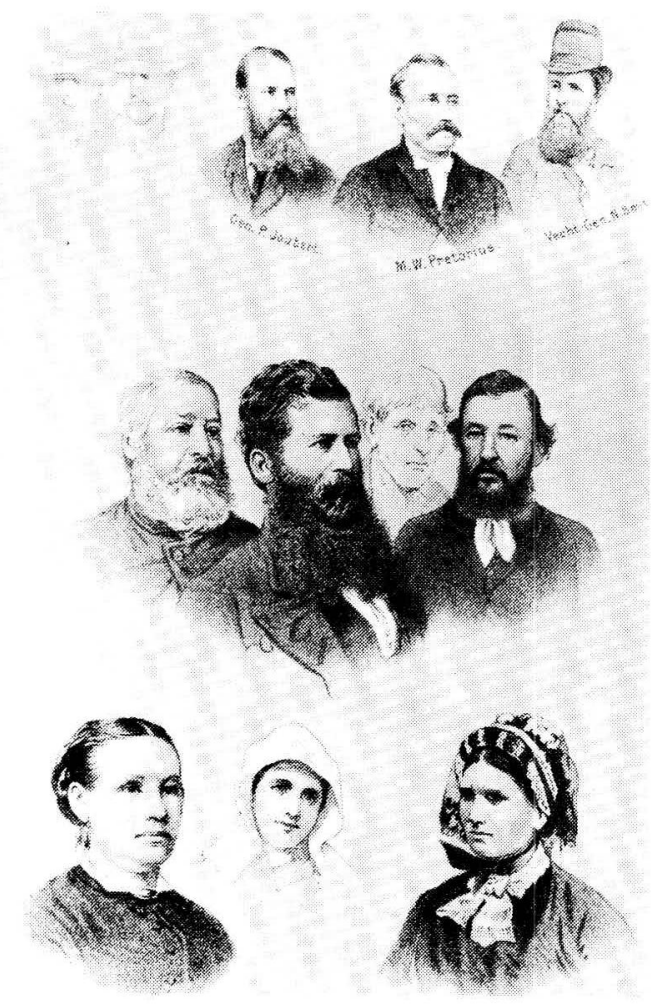

'Typen van Transvalers'

Potchefstroom klap, het die Engelse nog nie geglo dat die Boere werklik bereid was om in 'n volskaalse oorlog met Brittanje gewikkel te raak nie. Lanyon het die voorval as 'n impulsiewe daad wat op die ingewing van die oomblik begaan is, bestempel en verklaar dat die Boereleiers dit self nie eers verwag het nie. Selfs so laat as die einde van Januarie 1881 het hy nog nie die erns van die verset begryp nie en verklaar dat dit nie ver sou vorder nie, aangesien die meeste van die Boere nie eens geweet het waarom hulle veg nie en boonop ook nog swak bewapen was.

Die Britse owerhede het geweier om die Boere as oorlogvoerende moondheid te erken en hul verset as ' $n$ rebellie teen die Imperiale Regering beskou. Die Engelse koerant, 'The Times', het in die verband verklaar dat '... we should be no more than acting in accordance with recognised rules if we hang every one of them. ${ }^{\prime 8}$ Vir die Boere was dit bitter om as rebelle in hul eie land beskou te word. Kruger het hieroor gesê '... Wij weten niet, wat verachtelijker is, de annexatie van onze vrije Republiek of de behandeling van ons als rebellen'. ${ }^{9}$

Die Boere het die onsimpatieke houding aan Britse kant aan 'n gebrek aan begrip toegeskryf. Paul Kruger het die situasie so saamgevat:

'De groote afstand waarop wij leven van de centra der politieke beschaving, de weinige kennis die men heeft van onze geschiedenis maakt het zeer gemakkelijk onzen bijna wanhopigen strijd voor vrijheid en onafhankelijkheid voor te stellen als eene onbeteekende zaak, of wel erger, als eene onverantwoordelijke rebellie van ontevredene en domme boeren tegen een verlicht en menschlievend bestuur, dat om ons eigen bestwil, en om ons te redden van onze zwarte wijanden en ons te bewaren voor de onvermijdelijke gevolgen van onze eigen domheid en armoede, wel zoo goed heeft willen zijn om ons op te nemen in zijn rijk.' ${ }^{\prime 10}$

Met die oorlog ' $n$ voldonge feit, het die Britte vir geen oomblik aan die uitslag daarvan getwyfel nie. Colley, wat ook die opperbevelvoerder van die Britse troepe in Natal en die Transvaal was, het die Britse owerheid verseker dat die onderwerping van die Boere slegs 'n kwessie van tyd was. Getrou aan die Victoriaanse tradisie, het hy vir geen oomblik 'n Britse neerlaag oorweeg nie. Alhoewel Colley nie die Boere met soveel geringskatting soos die meeste van sy landgenote bejeën het nie, het hy die resultate wat hy met 'n klein lëer teen die Boere kon behaal, totaal oorskat.

Die uitbreek van die oorlog het maar min belangstelling by die algemene publiek in Engeland uitgelok, veral aangesien dit met die aanbreek van die Kersseisoen saamgeval het. Daarby het die deursnee Brit nie eers geweet waar die Transvaal op die wêreldkaart geleë was of watter soort mense daar gewoon het nie. Hulle kennis was gegrond op die onbesonne stories wat die Britse amptenare in Suid-Afrika vir die koerante in Engeland geskryf het. Wat hulle aanbetref het, was die Boere ' $n$ vuil en verslonsde spul onder wie luise algemeen voorgekom het en wat nooit hul klere uitgetrek het voordat dit van hul liggame afgeval het nie. Dit is dus nie verbasend dat hulle geglo het dat ' ... when the British Lion swished its tail, the rebellion of these ungrateful Boers, who had neither discipline nor training, would be swiftly terminated'. ${ }^{11}$

Die Britse verwagting dat hulle 'n vinnige en beslissende oorwinning oor die Boere sou behaal, is heeltemal te verstane, want op papier het hulle die Boere in elke opsig oorskadu. Teenoor die magtige Britse Ryk, op die kruin van sy mag en rykdom, het die klein, verarmde Boererepubliek 'n patetiese figuur geslaan. Die Transvaal kon in totaal skaars 7000 onopgeleide boere vir sy oorlogspoging monster, terwyl Brittanje tienduisende opgeleide soldate met wye 
gevegservaring kon mobiliseer.

Die oormaat selfvertroue wat die Britte uit hul getalsoorwig geput het, is verder versterk deur die lae dunk wat hulle van die Boer as soldaat gehad het. Hulle het met geamuseerde minagting op die Boere, wat in die ruwe werksklere waarmee hulle op die slagveld opgedaag het vir hulle meer na struikrowers as soldate gelyk het, neergesien. Wat hulle aanbetref het, was die Boere allesbehalwe soldate. Die Hertog van Cambridge het na die slag van Majuba gekla sy troepe in Suid-Afrika '... had been defeated by an army of deerstalkers. ${ }^{12}$ Selfs Colley met sy versigtiger benadering van die Boere het by geleentheid na die Boere as 'indisciplined rabble' verwys. Generaal Sir Evelyn Wood het beweer dat die Boere alleen goed was om beeste aan te jaag en swartes te skiet, terwyl 'n ander Britse offisier gereken het dat alhoewel baie van die Boere goed kon skiet, hulle sekerlik sonder vleis sou bly as die diere wat hulle gejag het ook gewere gehad het. ${ }^{14}$

Die Britse offisiere het geglo dat die doeltreffende organisasie, opleiding en dissipline van die Britse Leër aan hulle 'n onberekenbare voorsprong besorg het. Baie van hulle was ook oortuig daarvan dat die veggees van die ou Voortrekkers lankal dood was en dat die Boere van hul tyd 'n spul lafaards was. 'n Gebrek aan sport het hulle vet en dooierig gemaak en hulle kon ook nie meer so goed soos hul voorvaders skiet nie. Geen wonder dus dat een Britse offisier, kolonel Tucker, verklaar het dat hy sy eenheid slegs met pikstele sou bewapen en hulle dan dwarsdeur Suid-Afrika sou lei nie. ${ }^{15}$

Die opleiding, organisasie en dissipline wat die Britse soldaat so hoog aangeskryf het, het inderdaad by die Boere ontbreek. Tog het hulle oor ander kwaliteite beskik wat van hulle die mees formidabele teëstanders gemaak het waarmee die Britse Leër ooit te kampe gehad het. Hul bedrewenheid as perderuiters, hul ongeëwenaarde veldkennis en die ervaring wat hulle in die vele skermutselings met die swart volke opgedoen het, het van hulle 'n gedugte vyana gemaak. Die gebrek aan militêre dissipline is oorbrug deur 'n gemeenskaplike vryheidstrewe en 'n onwrikbare vertroue in die leiding en beskerming van die Hoër Hand. Kruger het die geloof en strewe mooi saamgevat toe hy gesê het: '. . W Wij vertrouwen op den Koning der Koningen ... Hij zal het voorzien ...' en verder, '. . Hetzij wij overwinnen, hetzij wij sterven: de Vrijheid zal in Afrika rijzen als de zon uit de morgenwolken, als de vrijheid rees in die Vereenigde Staten van Noord-Amerika. Dan zal het zijn van Zambezi tot aan Simonsbaai: Afrika voor den Afrikaner'. ${ }^{16}$

Die Boere het op hul beurt ook die Britse soldate met 'n mate van geamuseerdheid beskou. Dit was vir hulle onverstaanbaar dat die Engelse oral te voet met swaar pakke uitrusting op hul rûe beweeg het en hulself op die wyse hoogs kwesbaar teen die berede burgers gemaak het. Daarby het hul helderrooi uniforms en spierwit helmets van ver af 'n maklike teiken vir die Boereskerpskutters uitgemaak. Die Engelse gebruik om in die oop veld volgens vasgestelde reëls met nuttelose bajonette en gewere wat hulle nie behoorlik kon hanteer nie te wou veg, het vir die Boere na die toppunt van onnoselheid gelyk.

Net so skerp as wat die netjiese, helderkleurige uniforms van die Britse soldate van die verslete werksklere van die Boere verskil het, was die verskil tussen die Boer en Brit wat hul houding teenoor die oorlog aanbetref. Toe die oorlog eers aan die gang was, het die redes daarvoor vir die Britse soldaat vervaag en het hy net geveg omdat hy ' $n$ soldaat was. As soldaat moes hy ter wille van die eer en roem van die Kroon sukses behaal. Benewens die eer van die Kroon, het die Britse soldaat, veral die offisiere, dikwels in elke oorlog ' $n$ geleentheid gesien om vir homself onsterflike roem te verwerf. As hy in die proses sou sterf, was die eer des te groter. Soos soms verklaar is, was dit immers die plig van die Britse soldaat om mooi te lyk in vredestyd en in oorlogstyd 'n heldedood te sterf.

By die Britse offisier was daar ' $n$ byna fanatieke obsessie om in geen omsiandighede sy trots of waardigheid prys te gee nie, selfs nie ten koste van sy eie lewe nie. Uit vrees dat hy van lafhartigheid of 'n gebrek aan moed verdink sou word, het hy dikwels geweier om saam met sy manskappe dekking te neem wanneer vyandelike vuur getrek word. Ten spyte van die feit dat die Boere tydens elke geveg daarop gekonsentreer het om eerste die Britse offisiere dood te skiet, het hulle nooit 'n poging aangewend om hul rangkentekens te verberg nie.

Die Britse soldaat het vanweë sy beheptheid met persoonlike moed en dapperheid nie gehuiwer om tydens 'n geveg 'n gewisse dood tegemoet te storm nie. Die durf waarmee die Britse offisiere aan die voorpunt van hul manskappe in 'n geveg ingestorm het, was dikwels ' $n$ weerspieëling van 'n gees onder hulle wat oorlog tot weinig meer as 'n gevaarlike sportsoort vervlak het. Wanneer 
hulle teruggedryf is, het baie offisiere verkies om eerder ' $n$ heldedood op die plek te sterf, as om om te draai en na veiligheid te vlug. Om te vlug het nie by die waardigheid van ' $n$ offisier gepas nie.

Gegewe die hoë waarde wat die Britse soldaat aan roem en eer in oorlog geheg het, was hul minagting en onderskatting van die Boer as soldaat juis gedeeltelik gegrond op die oortuiging dat die Boere '... even lacked a fundamental martial spirit which could inspire men to die for honour and glory' 17 Hierin het die Engelse heeltemal gelyk gehad. Dit was nie vir die Boere lekker om oorlog te maak nie, daarvoor het hulle te veel waarde aan hul eie lewe geheg. Dit was vir hulle geen eer om ' $n$ heldedood vir hul vaderland te sterf as dit beteken het dat hul vrouens en kinders die gevare van die wildernis voortaan alleen sou moes trotseer nie.

Anders as by die Engelse het die rede vir die oorlog nooit in die gemoedere van die Boere vervaag nie. Dwarsdeur die stryd het dit by hulle om die herwinning van hul verlore vryheid en die beëindiging van Engelse heerskappy gegaan. Van die manier waarop die Engelse oorlog gemaak het, het hulle gesê dat die Engelse geveg het om te sterf, terwyl hulle geveg het om te leef. Gedwing in 'n oorlog waarvoor hulle nooit gevra het nie, het die Boere probeer om die Engelse te dood met die mins moontlike risiko van hul eie lewens. Met die klein reserwe aan mannekrag en feitlik geen aan ammunisie nie, het elke burger besef dat ongevalle tot ' $n$ absolute minimum beperk moes word en dat elke skoot moes tel.

Omdat die Boere nie daarin geïnteresseerd was om 'n heldedood te sterf nie, het hulle nie graag versterkte Britse stellings bestorm nie. As hulle dit wel gedoen het, het hulle dadelik teruggeval as dit blyk dat die Engelse suksesvol weerstand sou bied. Dit was vir die Boer geen skande om terug te val of te vlug as hy daardeur menselewens sou spaar nie. Eerder as om die risiko van lewensverlies te loop, het hulle hulle op 'n eerbiedige afstand verskuil en daarvandaan op die Engelse forte geskiet en op hul bedrewendheid as skerpskutters staatgemaak om skade aan te rig. Die Boere het dit oor die algemeen ook verkies om op die verdediging te veg, eerder as om aan te val. Dit het minder lewensverlies aan Boerekant meegebring en hulle het ook groter godsdienstige regverdiging in verdediging as in 'n aanval gevind.

Vanweë die hoë waarde wat die Boere aan menselewens geheg het, het elkeen in die hitte van die stryd op eie inisiatief gehandel. Anders as die Engelse het hulle van elke beskikbare tipe dekking gebruik gemaak en hulself nooit onnodig blootgestel nie. Hulle het ook nie op 'n bevel gewag om te skiet of te storm nie, maar het telkens op die geskikste oomblik gehandel. H. J. $C$. Pieterse het in die verband met verwysing na die slag van Majuba gesê: 'Die Boere het die eienaardigste manier van oorlog wat 'n mens jou kan voorstel. Elke burger is op sy eie. Elkeen maak klaar so vinnig as wat hy kan. Sodra hy klaar is, wag hy nie nog vir die ander kêrels nie, maar spring weg om die vyand te gaan aanval. So het hulle op 'n streep klaargekry en op 'n streep afgesit, berg uit."18 Dit was juis hierdie ongebondenheid aan vaste reëls en konvensies waarteen die gereglementeerde Britse soldaat hom in die oorlog so dikwels bloedneus geloop het.

Die Engelse was vanweë hulle oordrewe trots en eergevoeligheid traag om te besef en te erken wanneer die 'primitiewe' Boerekrygers hulle die loef afgesteek het. 'n Engelse ooggetuie by die slag van Laingsnek het verklaar '. . . dit is by ons Engelse 'n soort vaste reël, omdat ons 'n hekel daaraan het om verslaan of oorwin te word, om wanneer ons 'n neerlaag ly, ons teëparty te verwyt dat hy teenstrydig met die reëls van beskaafde oorlogvoering opgetree het'. ${ }^{19}$ By die

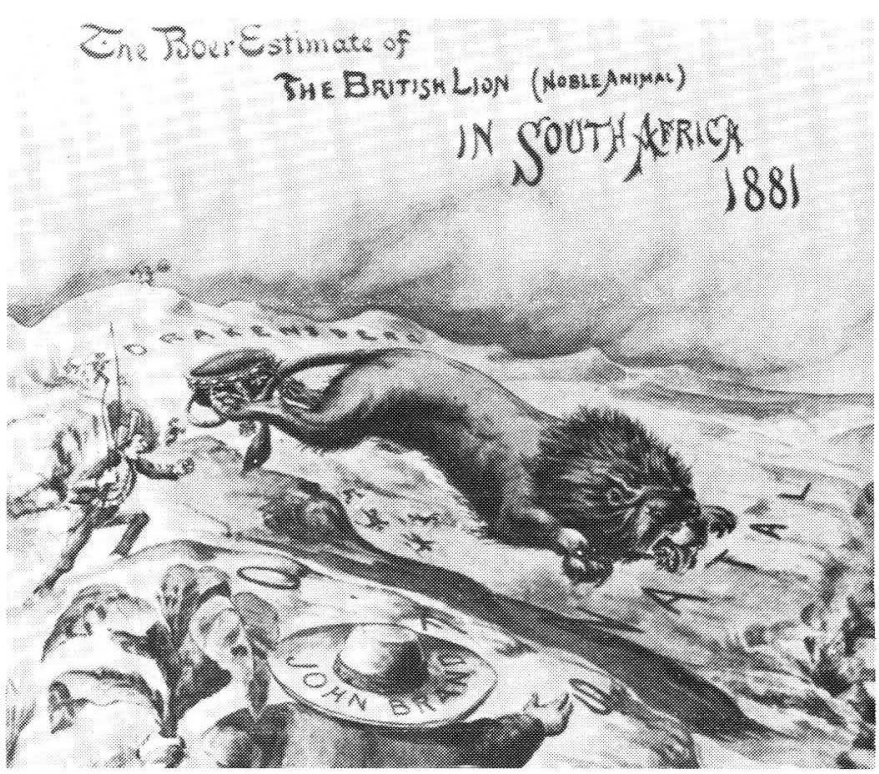

'The Boer Estimate of the British Lion (Noble Animal) in South Africa 1881' (Foto: Africana Museum Jhb)

slag van Bronkhorstspruit is die Boere as barbare uitgekryt en van koelbloedige moord beskuldig, nadat hulle wel 'n duidelike ultimatum aan kolonel Anstruther gerig het om nie met sy aanmars na 
Pretoria voort te gaan nie. Die Boere is ook by verskeie geleenthede daarvan beskuldig dat hulle doelbewus op gewondes en ambulanswaens geskiet het of wit vlae verontagsaam het. In hierdie beskuldigings het die Engelse dikwels vergeet dat die Boere se enigste gevegservaring teen die barbaarse swart volke van Afrika was en dat hulle dikwels geen kennis of begrip van die etiket van 'beskaafde' oorlogvoering gehad het nie.

Die Boere kon die Engelse beskuldigings ten opsigte van Bronkhorstspruit nie begryp nie. Hulle het gevoel dat die Britte bereid was om die swartes die verskriklikste wandade te vergewe, maar dat wanneer die Boere hulle op 'n eerbare manier beveg, hulle as moordenaars uitgekryt is. ' $n$ Vrystaatse burger het in die verband aan die 'Bloemfonteinsche Express' geskryf dat '... Indien te IsandhIwana 10,000 Zulus onverwacht en zonder waarskuwing 1000 of 1200 Engelsche soldaten aanvallen en hen met assagaaijen vermoorden, zelfs niet een enkele der laaste tien sparende, die te vergeefs om genade moeten gesmeekt hebben, worden de Zulus dapperen genoemd en de moord een ramp ... Indien slechts een handvol Boeren, vechtende voor hun land, dat schandelijk van hen gestolen is, een eerlijke waarschuwing zendt aan Britsche soldaten om terug te keeren van waar zij kwamen en na die waarschuwing strijden en overwinnen, sparende de zich overgaven, verplegende de gewonde en toelatende diegene, die zij presoniers gemaakt hebben, om vrij te gaan en terug te keeren naar het land van hunne heeren, om daar ontvangen te worden als helden, dan worden deze Boere verradelijke lafaards, barbaren genoemd. $O$ ! de zegen van een zwart vel in een oorlog met die Engelschen! waarom zijn de Boeren geen zwarten, in plaats van Hollandsche Afrikanen, en hoe verschillend zouden hunne daden beoordeeld worden. ${ }^{20}$

Die Boere het geglo dat God self geregtigheid sou laat geskied en die onregte wat teenoor hulle gepleeg is sou herstel. Die beslissende oorwinning wat hulle met die slag van Majuba op 27 Februarie 1881 oor die Engelse behaal het, het hierdie geloof bevestig. Hulle het verklaar dat die Engelse niks anders kon verwag as om die toorn van die Almagtige op te wek deur op Sondag oorlog te maak nie. Die digte mis wat hulle verhoed het om die Engelse na die slag te agtervolg en af te maai, het hulle beskou as 'n teken van God dat dit genoeg was en dat die wraak die mens nie toekom nie.
Die wyse waarop Boer en Brit die uitslag van die oorlog verwerk het, is tekenend van die verskil in hul benadering tot die oorlog. Die Boere het hul oorwinning nie aan eie krag gedank nie, maar aan die bestiering van God. Soos Kruger dit gestel het: 'Ons roem (die oorwinning) nie op menslike krag nie, dit is die Here God wat ons gehelp het

Hy het ons gebede verhoor'. ${ }^{21}$ ' $n$ Ander burger het verklaar: 'Van het begin van den oorlog heeft de Heere ons alles van onzen vijand in de hand gegeven, niet alleen ammunitie, maar daarbij kost en kleeren, zoodat, als wij een slag gemaakt hebben, wij genoeg buit gekregen hebben om een tweede slag te leveren'. ${ }^{22}$ Die Boere het hulself alleen maar as instrumente in Gods hand gesien. Deur Sy krag het hulle '. . . die magtige moondheid wat hulle so onregverdig aangeval het, getoon dat selfs die swakste volk wat vir sy vryheid veg, instaat is om wonders van dapperheid te verrig'. ${ }^{23}$

Aan die Engelse kant het menige soldaat na die bottel gegryp om aan die vernedering en teleurstelling van die oorlog te ontsnap. Hul trots wou hulle eenvoudig nie toelaat om te aanvaar dat hulle verloor het nie. Die blaam vir hulle militêre mislukkings is hoofsaaklik voor Colley se deur gelê en daar was 'n sterk gevoel onder hulle dat die oorlog hervat moes word om hul prestige te herstel. Koningin Victoria het die algemene gevoel onder die Britte mooi gereflekteer toe sy op 6 Maart 1881 in haar dagboek geskryf het: 'I do not like peace before we have retrieved our honour'. ${ }^{24}$

Dit is te verstane dat die Britte hul neerlaag baie diep gevoel het. Dit was die eerste keer sedert die Krim-oorlog dat hulle teen 'n Blanke vyand geveg en verloor het. Die feit dat die Boere as 'n dom en primitiewe vyand gereken is, het die vernedering des te groter gemaak. Vir die verslane Britse Leër was daar dus geen heldeontvangs in Engeland nie. Een van die garnisoen-soldate het gekla dat ' . . . no hand was held out to greet us ... if we mentioned the fact of our late defence, we are met with silence'. ${ }^{25}$

Alhoewel daar na die oorlog steeds diegene was wat die Boere met minagting bejeën het, het die oorlog tog die Britse soldate se houding teenoor die Boere verander. Namate daar met hulle op die slagveld kontak gemaak is, het die vroeëre minagting geleidelik plek gemaak vir respek en soms selfs vir bewondering. Colley het dit voor die slag van Majuba op sy offisiere se harte gedruk dat hulle met ' $n$ vasberade volk te doen het wat as hulle een keer storm, nooit weer die 
rug op die vyand sou draai nie. Die wanindruk waaronder die meeste Britse soldate verkeer het, blyk duidelik toe 'n offisier hierop verwytend aan Colley gesê het: 'Maar ons is gesê dat ons 'n klompie lafhartige rebelle moes kom gevange neem en nou moet ons verneem van ' $n$ volk, en 'n volk wat nie die rug gaan keer nie'. ${ }^{26}$

Die illusie dat die Boere 'n spul lafaards was, swak geskiet het en te onnosel was om teen die Engelse te veg, is ook gedurende die oorlog die nek ingeslaan. Colley, wat vanweë sy intieme betrokkenheid by die al groter veldslae van die oorlog waarskynlik die beste in staat was om die Boer as soldaat te oordeel, het gesê: 'I must say they (die Boere) were no cowards, exposing themselves freely to artillery fire and coming boldly down the field to meet our men'. ${ }^{27}$ Uit Colley se nagelate briewe en oorlogsberigte het sy biograaf later verwys na die '. . . mobility of the enemy, the extra-ordinary accuracy of their rifle fire; their coolness, courage and instinctive knowledge of war ....' en verder '. . . every Boer bullet comes with unerring accuracy of direction and elevation, the fire on our side was much less effective'. ${ }^{28}$

Die Britte moes aan die einde van die oorlog toegee dat die Boere vanweë die omgewing waarin hulle geleef en die swart stamme wat hulle moes trotseer, in uitmuntende berede infanteriste ontwikkel het. Die wyse waarop die Boereleiers die Britte met fyn krygsvernuf uitoorlê het, het ook die respek van menige Britse offisier afgedwing. Generaal Sir William Butler het generaal Nicholaas Smit bestempel as '... one of the ablest leaders of mounted infantry that have appeared in modern war . . . ' 29 Colley het Smit beskryf as '... an intelligent and fine man, courteous and human in everything connected with the wounded and gallant in action'. ${ }^{30}$

Die wyse waarop die Boere alles in die stryd gewerp het om hul vryheid en onafhanklikheid te herwin, het die bewondering van die ganse Europa afgedwing. Dit is onteenseglik bewys dat daar geen sprake was van 'n klomp dom, agterlike en liggelowige Boere wat deur gewetenlose leiers uit eie belang en vanweë persoonlike heersug tot opstand aangehits is nie. Elke Boer was 'n patriot, elke Boer was persoonlik by die stryd betrokke en was bereid om sy lewe ter wille van die saak van vryheid op te offer. Wat die 'Round Heads' vir Engeland gedoen het, wat Garribaldi se legioene vir Italië gedoen het en wat die Bostonse koopliede vir Amerika gedoen het, het die Boere vir hul Republiek gedoen. ${ }^{31}$

\section{BRONNE}

1. Cachet, F. Lion: De Worstelstrijd der Transvalers. Höveker \& Zoon, Amsterdam, 1883.

2. Carter, Thomas Fortescue: A Narrative of the Boer War: its causes and results, London: John Macquern, J. C. Juta \& Co, Cape Town, etc., 1896.

3. Heyns, Michiel: Die Eerste Vryheidsoorlog, 1877-1881 (Ongepubliseerde D. Litt.-proefskrif, Universiteit van Pretoria, Januarie 1941.

4. Lehmann, Joseph H: The First Boer War. Jonathan Cape Ltd, London, 1972.

5. Norris-Newman, Charles L: With the Boers in the Transvaal and Orange Free State in 1880-1. Second edition, Abbot, Jones \& Co., London, no date.

6. Pieterse, H. J. C.: Volksaltare of 'n veteraan van die Eerste Vryheidsoorlog (Persoonlike Herinneringe van P. C. Joubert). Tweede druk, Nasionale Pers Beperk, Kaapstad, ens., 1948.

7. Preller, Dr. Gustav S.: Daglemier in Suid-Afrika (Oorsig van die Geskiedenis van Suid-Afrika, van die vroegste tye.) Wallach's Bpk, 1937.

8. Proclamatie: Gouvernement Der Zuid-Afrikaansche Republiek, uitgegee deur die Driemanschap, Paardekraal, Desember 1880.

9. Ransford, Olivier: The Battle of Majuba Hill (The First Boer War). John Murray, London, 1967.

10. Staats Courant Der Zuid-Afrikaansche Republiek (Buitengewone uitgawe) Deel 1 No 6. Potchefstroom, 16 Februarie 1881.

11. Staats Courant Der Zuid-Afrikaansche Republiek (Buitengewone uitgawe) Deel 1 No 7. Potchefstroom, 23 Februarie 1881.

12. Weilbach, J. D. en Du Plessis, C. N. J.: Geschiedenis van de Emigranten boeren en van Den Vrijheids- Oorlog. Saul Soloman \& Co, Kaapstad, 1882

* Kapt G. E. Visser, BA Hons is verbonde aan dié Dokumentasiediens van die SAW

\section{VOETNOTE}

1. Proclamatie: Gouvernement Der Zuid-Afrikaansche Republiek, uitgevaardig deur die Driemanschap, Paardekraal, Desember 1880.

2. Buitengewone uitgawe van die Staats Courant Der ZuidAfrikaansche Republiek Deel 1 No 6 gedateer 16 Februarie 1881, 23, kolom 2, brief van S. J. P. Kruger en W. Eduard Bok gedateer 7 Februarie 1881 aan die President en Volksraad van die Oranje Vrystaat.

3. Ibid.

4. Ibid, p 25, kolom 1 .

5. Joseph H. Lehmann: The First Boer War, $p 80$.

6. Ibid, p 93

7. Olivier Ransford: The Battle of Majuba Hill, p 34

8. Joseph H. Lehmann: The First Boer War, p 139

9. Buitengewone uitgawe van die Staats Courant Der ZuidAfrikaansche Republiek Deel 1 No 6 gedateer 16 Februarie 1881, p 26, kolom 3, brief van S. J. P. Kruger en W. Eduard Bok gedateer 7 Februarie 1881 aan die President en Volksraad van die Oranje Vrystaat.

10. Ibid, p 23, kolom 1-2.

11. Joseph $H$. Lehmann: The First Boer War, $p 125$.

12. Oliver Ransford: The Battle of Majuba Hill, p 41.

13. Joseph H. Lehmann: The First Boer War, p 111.

14. Ibid.

15. Ibid, p 95.

16. Buitengewone uitgawe van die Staats Courant Der ZuidAfrikaansche Republiek Deel 1 No 6 gedateer 16 Februarie 1881, p 26, kolom 3, brief van S. J. P. Kruger en W. Eduard Bok gedateer 7 Februarie 1881 aan die President en Volksraad van die Oranje Vrystaat.

17. Joseph H. Lehmann: The First Boer War, p 104

18. H. J. C. Pieterse: Volksaltare, pp 75-76

19. Buitengewone uitgawe van die Staats Courant Der ZuidArfikaansche Republiek Deel 1 No 7, gedateer 23 Februarie 1881, berig Het Gevecht Te Langesnek: verslag van een Engelsche ooggetuie.

20. Buitengewone uitgawe van die Staats Courant Der ZuidAfrikaansche RepubliekDeel 1 No 6, gedateer 16 Februarie 1881, p 28 kolom 1, berig Inboorling en Afrikaner.

21. T. H. Carter: A Narrative of the Boer War, p 301.

22. F. Lion Cachet: De Worstelstrijd der Transvalers, $\mathrm{p} 544$.

23. Michiel Heyns: Die Eerste Vryheidsoorlog, 1877-1881,p 379-380.

24. Oliver Ransford: The Battle of Majuba Hill, p 125.

25. Joseph H. Lehmann: The First Boer War, p 284.

26. H. J. C. Pieterse: Volksaltare, p 72 .

27. Ibid, $p 71$

28. Ibid.

29. Oliver Ransford: The Battle of Majuba Hill, p 43.

30. Ibid.

31. Michiel Heyns: Die Eerste Vryheidsoorlog, 1877-1881, p 382. 